Kaptalan A. O., Stoyanov A. N., Ostapenko I. O., Kirchev V. V., Yermuraki P. P. Peculiarities of formation and clinical course of symptomatic epilepsy as a result of cranial injury. Journal of Education, Health and Sport. 2021;11(1):140-152. eISSN 2391-8306. DOI http://dx.doi.org/10.12775/JEHS.2021.11.1.014

https://apcz.umk.pl/czasopisma/index.php/JEHS/article/view/JEHS.2021.11.1.014

https://zenodo.org/record/4469696

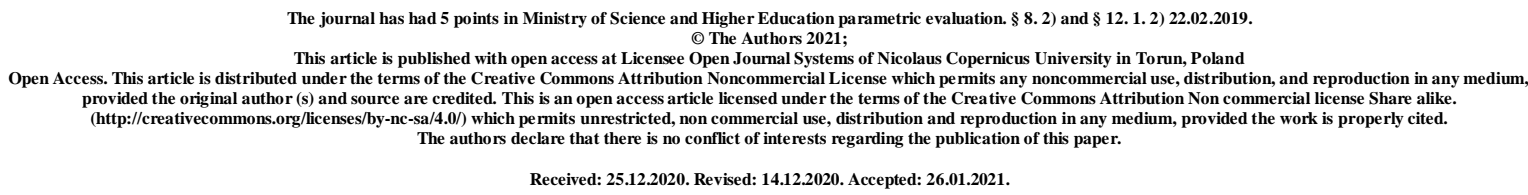

UDC 616.853.31-001.24-091.8

\title{
PECULIARITIES OF FORMATION AND CLINICAL COURSE OF SYMPTOMATIC EPILEPSY AS A RESULT OF CRANIAL INJURY
}

\author{
A. O. Kaptalan, A. N. Stoyanov, I. O. Ostapenko, V. V. Kirchev, P. P. Yermuraki \\ *State Institution Ukrainian Research Institute of Transport Medicine \\ Odessa National Medical University
}

\begin{abstract}
Post-traumatic epilepsy (PTE) is a formidable and frequent consequence of traumatic brain injury (TBI) in the long term. 41 patients with PTE were examined, mostly men of working age. The time of formation of PTE after was $14.3 \pm 1.4$ months, which decreased depending on the severity of brain injury, the average frequency of seizures was $2.93 \pm 0.8$ per month.

Focal seizures were mainly registered $(63.4 \%, \mathrm{p}<0.05)$, and taking into account the focal onset in bilateral tonic-clonic seizures, this figure reached $90.2 \%(\mathrm{p}<0.05)$. Among the selected syndromes, except for direct PTE, autonomic dysfunctions (87.8\%) with paroxysmal course $(58.5 \%)$ prevailed, especially in persons with moderate trauma $(r=0.51, p<0.05)$.

Typical comorbid symptoms in people with PTE were cognitive deficits, which correlated with the severity of TBI, as well as depressive and anxiety symptoms. Depressive layers were more often observed in the presence of the focal component of seizures $(94.7 \%, \mathrm{p}$ $<0.05)$, temporal localization of the pathological process and predominant vagotonia. Anxiety manifestations affected all types of attacks on the background of sympathicotonia $(83.3 \%, p$
\end{abstract}


$<0.05$ ), which in our opinion improved the implementation of crisis conditions, which were observed in $66.7 \%$ of cases.

Key words: post-traumatic epilepsy; clinical course; diagnosis; autonomic system

\title{
ОСОБЛИВОСТІ ФОРМУВАННЯ ТА КЛІНІЧНОГО ПЕРЕБІГУ СИМПТОМАТИЧНОЇ ЕПІЛЕПСІЇ ВНАСЛІДОК ЧЕРЕПНО-МОЗКОВОЇ ТРАВМИ
}

\author{
А. О. Капталан", О. М. Стоянов, І. О. Остапенко, В. В. Кірчев, П. П. Срмуракі
}

Український науково-дослідний інститут медицини транспорту МОЗ України“

Одеський національний медичний університет

Посттравматична епілепсія (ПТЕ) є грізним і частим наслідком черепномозкової травми (ЧМТ) у віддаленому періоді. Обстежено 41 пацієнт з ПТЕ, переважно

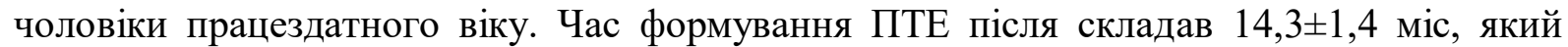
скорочувався в залежності від тяжкості травми мозку, середня частота нападів склала $2,93 \pm 0,8$ в міс.

Переважно реєструвалися фокальні напади $(63,4 \%, \mathrm{p}<0,05)$, а $з$ урахуванням фокального початку при білатеральних тоніко-клонічних нападах цей показник сягав 90,2\% (p<0,05). Серед виділених синдромів, окрім безпосередньо ПТЕ, превалювали вегетативні дисфункції (87,8\%) з пароксизмальним перебігом (58,5\%), особливо в осіб з перенесеною ЧМТ середньої тяжкості (r=0,51, $\mathrm{p}<0,05)$.

Характерними коморбідними симптомами у осіб з ПТЕ були когнітивний дефіцит, який корелював 3 тяжкістю перенесеної ЧМТ, а також депресивні та тривожні симптоми. Депресивні нашарування частіше спостерігалися при наявності фокального компоненту нападів $(94,7 \%, \mathrm{p}<0,05)$, скроневої локалізації патологічного процесу та переважної ваготонії. Тривожні прояви зачіпали усі типи нападів на тлі симпатикотонії $(83,3 \%, \mathrm{p}<0,05)$, що на наш погляд поліпшувало реалізацію кризових станів, які спостерігалися у $66,7 \%$ випадків.

Ключові слова: посттравматичная епілепсія; клінічний перебіг; діагностика; вегетативна система 
Introduction. Traumatic brain injury is a multidisciplinary problem involving many medical specialties.

Consensus data on the study of brain diseases in Europe indicate that more than 700 thousand people suffer from the effects of traumatic brain injury (TBI) [1-3]. A common complication of TBI is post-traumatic epilepsy (PTE), which is a chronic disease that develops after a brain injury and is characterized by repeated unprovoked seizures, impaired motor, sensory, vegetative and mental functions due to excessive neuronal discharges $[4,5]$.

The aim of the study was to study the features of the formation and clinical course of symptomatic epilepsy due to trauma.

Materials and methods of research. 41 patients with PTE were examined. In order to confirm the diagnosis, anamnesis data, outpatient or inpatient documents, interviews of patients, accompanying persons were used to establish the fact of TBI and the related attack; also the following was taken into account: the presence of EEG monitoring, which may confirm the epileptic nature of the attack; the presence of CT, MRI, which confirm the fact of trauma, clarified the factors that led to the attack for a possible clarification of non-traumatic etiology. The diagnosis of PTE was established at confirmation of repeated (not less than two) unprovoked attacks after the transferred TBI.

To determine autonomous tone (AT), a questionnaire was used for rapid diagnosis of AT [6], the psychometric condition was studied using a hospital scale of anxiety and depression, short-term and long-term memory - according to a test for memorizing 10 words according to the A. R. Luria's method [6].

Results. The majority of respondents were men (75.6\%). All patients were of working age, the mean values of which were $30.7 \pm 2.4$ years. At the same time, $85.4 \%$ are people from 18 to 40 years old.

According to the severity of trauma in accordance with the anamnestic data, the distribution of patients was as follows: moderate $-73.2 \%$, mild TBI $-12.2 \%$, severe trauma $14.6 \%$.

The time of formation of PTE or epileptogenesis, i.e. the time interval between the received TBI and re-attack after it averaged 14.3 \pm 1.4 months. At the same time the reduction in the degree of severity of a brain injury in the anamnesis is registered. Inmild TBIit made $21,4 \pm 2,1$ months; the average severity of TBI $-14.4 \pm 1.8$ months $(p<0,05)$; severe TBI 8.0 \pm 2.0 months $(\mathrm{p}<0,05)$.

The number of seizures in patients at the beginning of the study ranged from 1 to several weeks to 1-3 every 3 months. People with longer intervals were not included in the 
survey. The maximum number was at an interval of one to three months. The average frequency of attacks in the entire surveyed contingent was $2.93 \pm 0.8$ per month.

The clinical manifestations were dominated by focal seizures, which were registered in 26 patients $(63.4 \%, \mathrm{p}<0.05)$, of which seizures without loss of consciousness predominated $(18-69.2 \%)$. Bilateral tonic-clonic seizures were observed in 15 patients $(36.6 \%)$. Of these, with focal onset $-11(73.3 \%, \mathrm{p}<0.05)$. Thus, the presence of the focal component of seizures in clinical observations was $90.2 \%(\mathrm{p}<0.05)$.

Bilateral tonic-clonic cases predominated in cases of mild TBI $(83.3 \%)$, in one case they had a focal origin. In severe trauma, "focal" was recorded in all cases, with $66.7 \%$ was characterized by further bilateralization of neuronal excitation.

The clinical picture of the distant period of trauma in most cases was determined by a set of different syndromes (autonomous dysfunction, liquid-dynamic, vestibular, cerebralfocal, asthenic, subcortical), which in some cases acted as leading, in others - concomitant manifestations. It should be noted that each patient had a combination of at least two such syndromes, and given that PTE is also interpreted as a syndrome of the effects of trauma (Fig. $1)$.

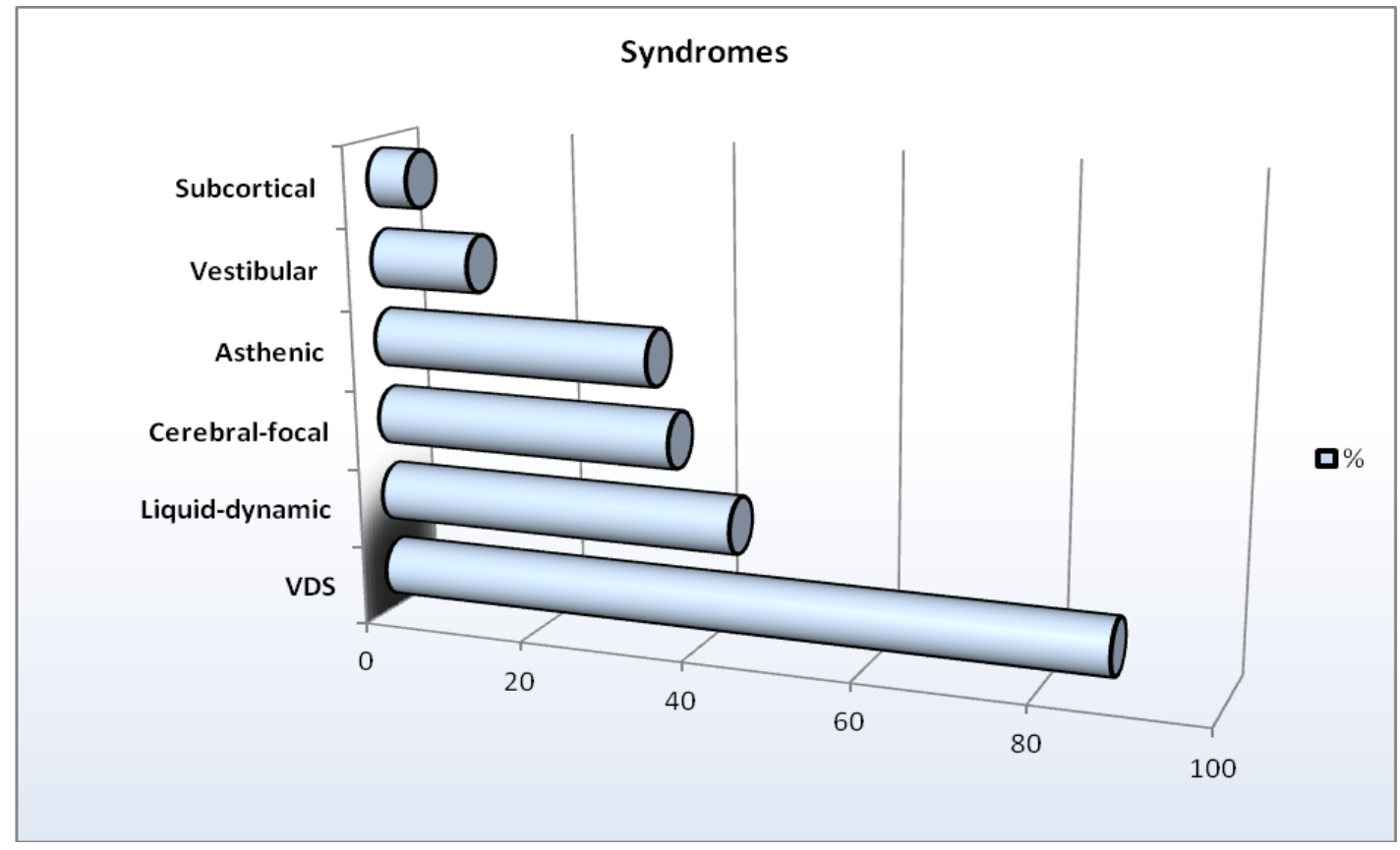

Fig. 1 - The main identified syndromes in the examined contingent of patients with PTE $(\mathrm{n}=41)$ 
Headache (HA) was observed after TBI and accompanied the development of all posttraumatic syndromes, primarily PTE. It is known that there are no specific mechanisms of post-traumatic HA, it can provoke tension headaches (THA), migraine-like, migraine HA.

Chronic post-traumatic HA was observed in 35 (85.4\%) patients. In 22 (62.9\%) of them, according to the criteria of the ICD-3, THA prevailed. In 5 (14.3\%) cases, clinically and according to ophthalmoscopy and ultrasound diagnostics, HA was associated with vascular disorders. In 4 patients $(11.1 \%)$ had a migraine. 4 (11.1\%) patients described neuralgic pain with irradiation along the nerve trunks (Fig. 2).

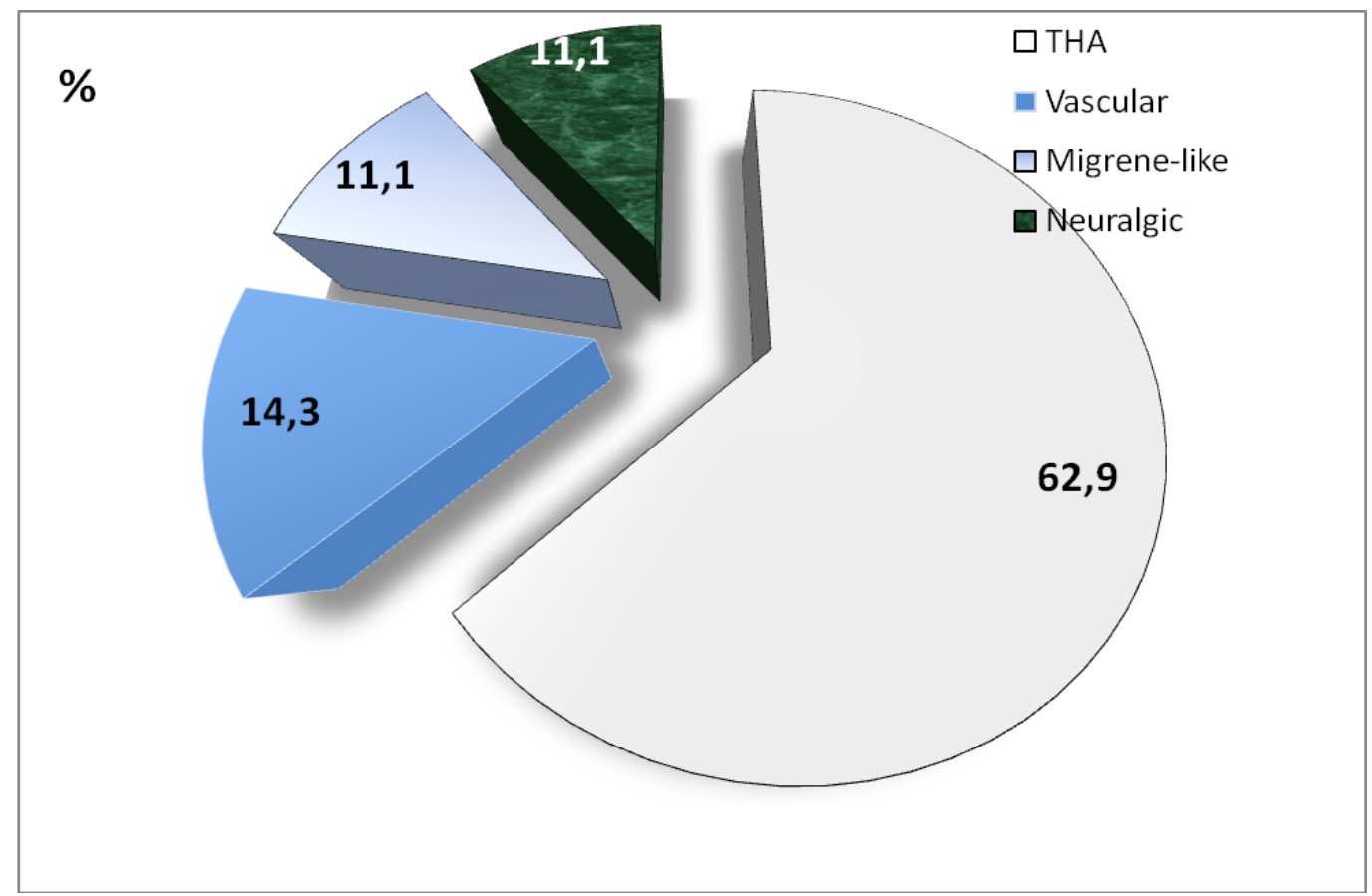

Fig. 2 - Relative distribution of clinical variants of cephalgia in persons with chronic post-traumatic HA $(n=41)$

Among the main complaints were: pain in 11 (26.8\%) cases with muscle tension as manifestations of myofascial dysfunction in the neck and shoulder girdle and with pathological impulses from proprioceptors that may have exacerbated the effects of angiospasm in the vertebral artery. In our opinion, these circumstances were an additional reflex stimulus for the development of symptomatic epilepsy.

An increase in blood pressure was registered in 9 patients (21.9\%). Noise in the head occurred in $6(14.6 \%)$, hearing loss in $8(19.5 \%)$ patients.

Complaints of memory disorders were filed by 34 (82.9\%) subjects. Patients indicated the impossibility of retaining the test material in memory. In some cases, with the 
predominance of vegetative disorders, complaints of memory disorders were mainly associated with asthenia, fatigue, and stressful situations.

Among the complaints of sleep disorders in 23 patients $(56.0 \%)$, the phenomena of dysomnia and hypersomnia prevailed. In $29.3 \%$ - intrasomnic disorders were manifested by frequent awakenings, a feeling of "superficial", "shallow" sleep. Awakenings were caused by nightmares, pain, increased heart rate, urge to urinate and other factors.

The presence of complaints of emotional lability was registered in 25 (60.9\%) for mood swings, which could go into a state of anxiety (Fig. 3).

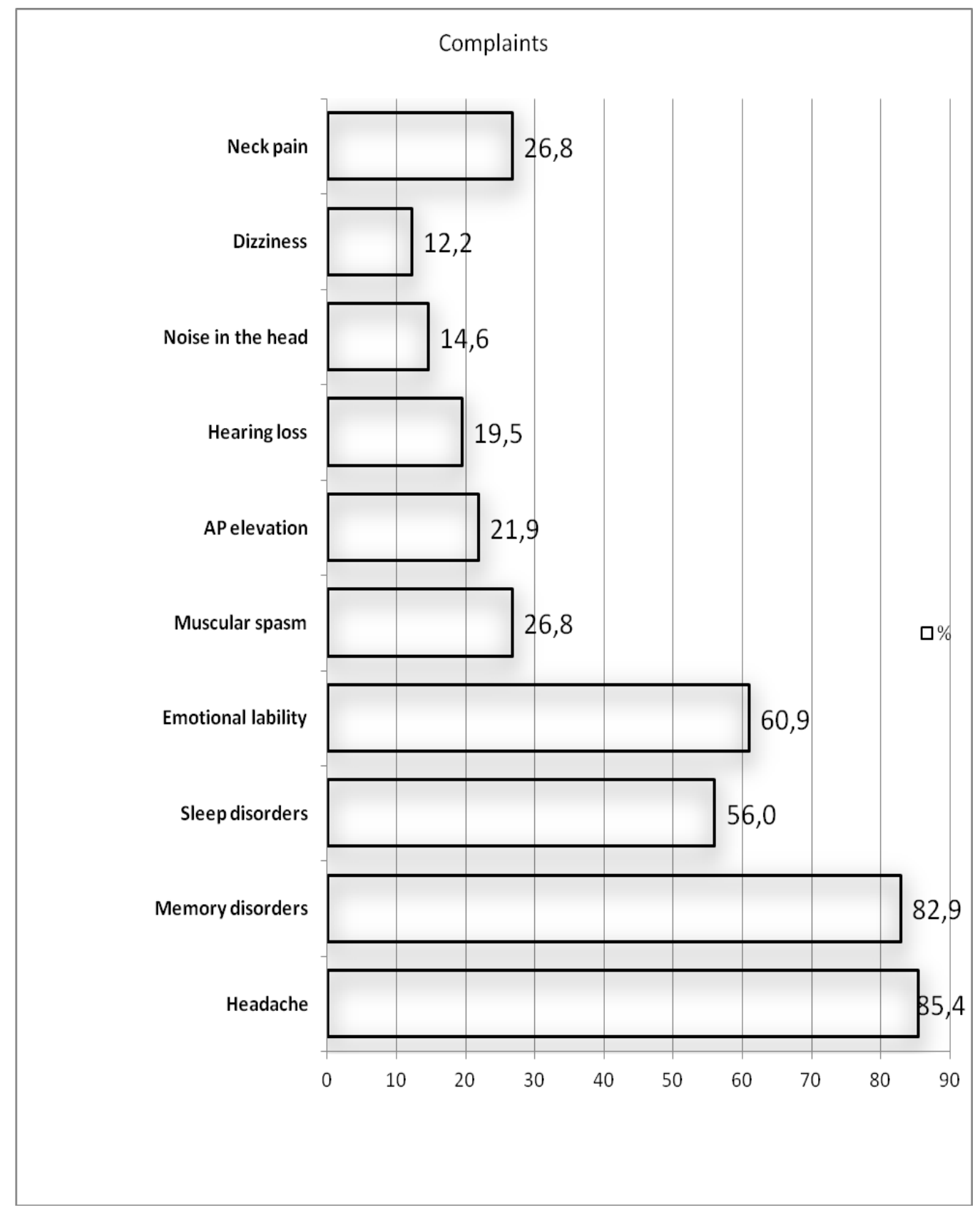

Fig. 3 - Relative distribution of the main complaints and subjective experiences of the examined contingent of patients 
According to the data of rapid diagnosis of vegetative tone (VT) [6] in the examined contingent of patients with PTE more often showed sympathicotonia $(56.1 \%, \mathrm{p}<0.05)$, a quarter of cases were vagotony $(24.4 \%)$, rarely diagnosed with eutonia $(19,5 \%)$.

We conducted a study of the relationship between existing VT with the severity of trauma (Fig. 4).

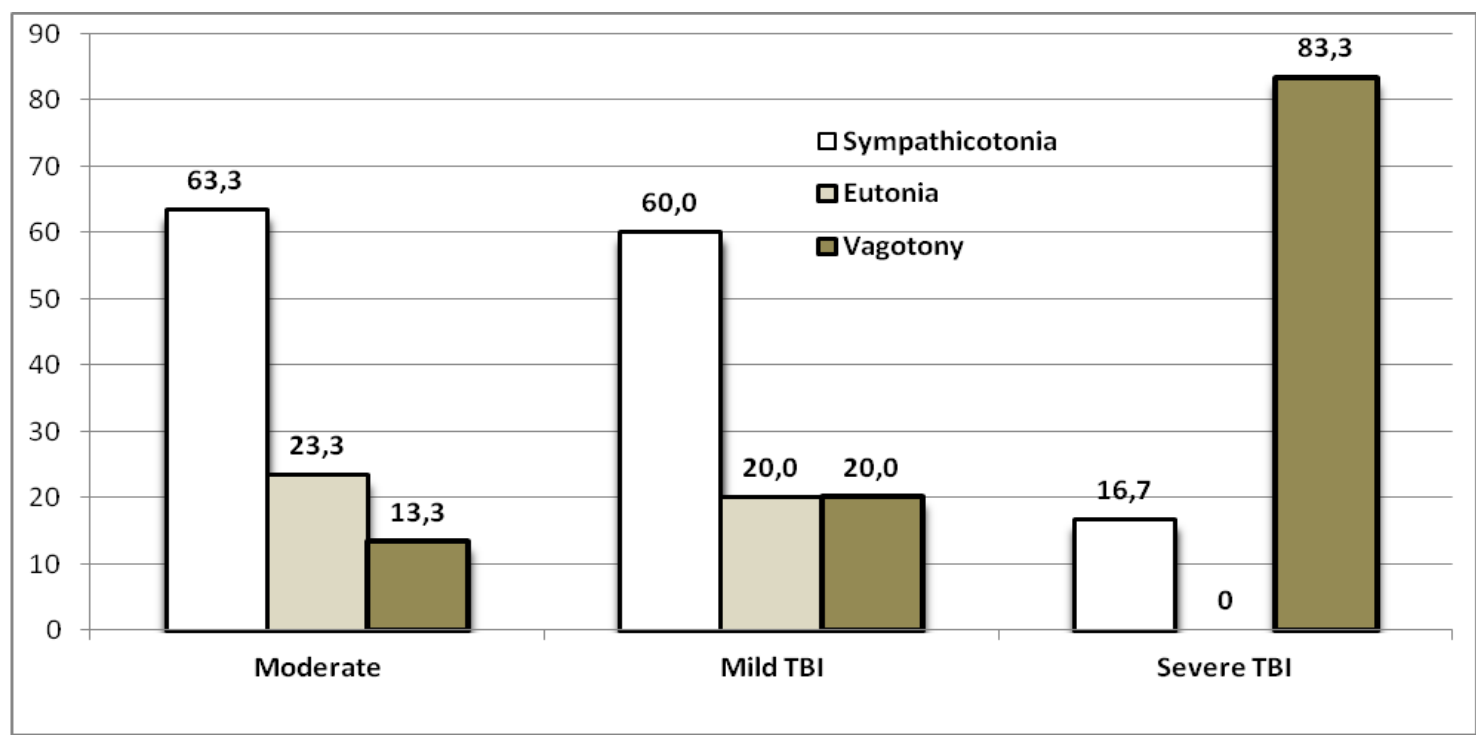

Fig.4 - Relative distribution of the number of patients depending on the severity of trauma in the anamnesis

The obtained data indicate that in the long-term period of mild TBI and in moderate TBI the values of VT in the direction of sympathicotonia were maximum $(60.0 \%$ and $63.3 \%$, respectively, $\mathrm{p}<0.05)$. At the same time, in severe TBI vagotonia significantly prevailed $(83.3 \%)$.

The relationship between the direction of VT with the types of seizures, which may be an important aspect of determining the pathogenetic components of epileptogenesis of PTE (Fig. 5).

In the presence of sympathicotonia and normal distribution of VT, the ratio of focal seizures related to bilateral tonic-clonic seizures significantly prevails $(p<0.05)$. In the presence of vagotonia, these indicators were less significant, but the number of bilateral attacks with focal onset increased.

The clinic of focal seizures also had certain patterns: in cases of sympathicotonia, focal seizures with impaired awareness occurred in $50.0 \%$ of cases $(\mathrm{p}<0.05)$. In eutonia or vagotonia this type of attacks was rare $(p>0,05)$. 


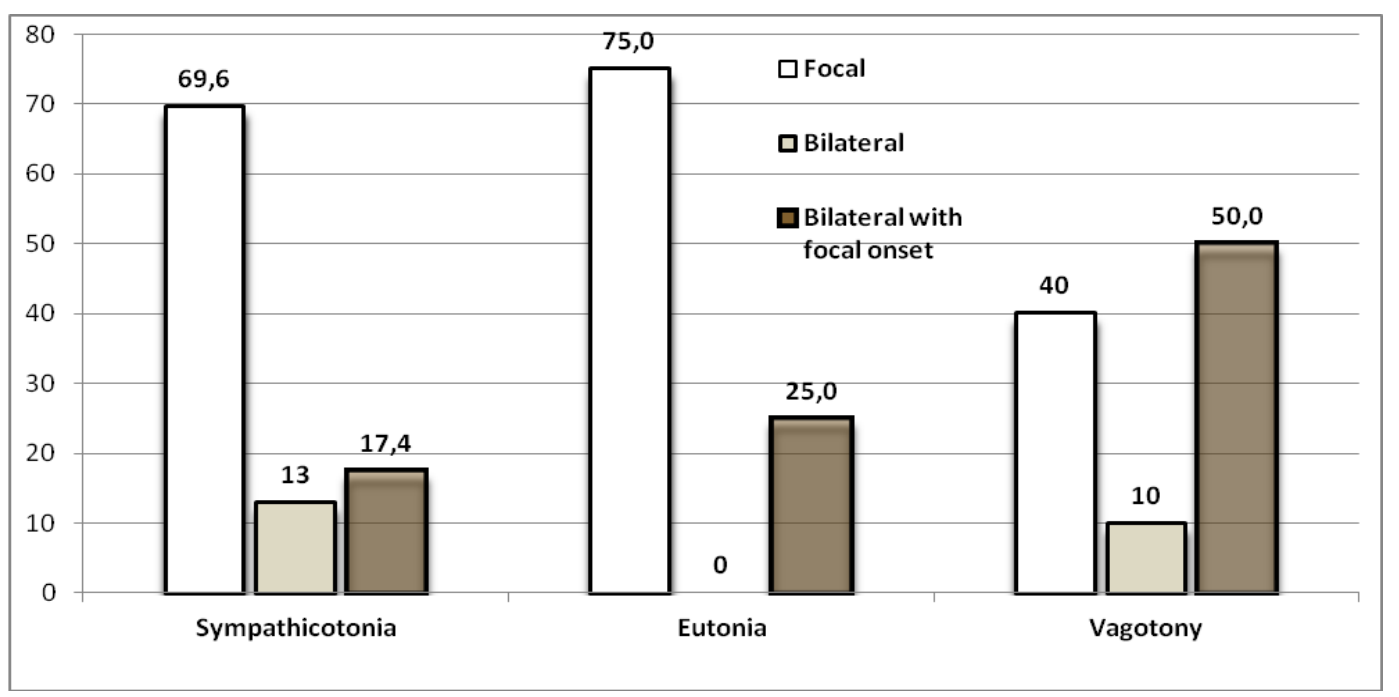

Fig. 5 - Relative distribution of types of attacks at different directions of VT $(n=41)$

The state of the vegetative system was studied in comparison with the terms of PTE formation. In vagotonia their maximum shortening was revealed, and average values were $12,3 \pm 2,1$ months that is $2,2 \pm 0,2$ months less, than at a sympathetic orientation of VT and on $4,2 \pm 0,3$ months - in eutonia $(\mathrm{p}<0.05)$.

The above may indicate irritation of the vagus structures where its afferent conductors open access through the brainstem to the associated areas of the brain. Also, the nuclei of this cranial nerve and its reflex arcs are involved in the occurrence of short-term focal seizures.

Neuroimaging methods confirmed the presence of structural changes in the brain as a result of trauma, especially in the acute period of brain injury, as well as on tomograms in the remote period upon arrival at the hospital. They correlated with the severity of the pathological process. The revealed structural changes on the tomograms of the brain in the anamnesis indicate damage and consequences of trauma. Post-traumatic bone defects of the skull in 19 patients $(46.3 \%)$, scar-atrophic injuries - $22(53.7 \%)$, post-traumatic cysts (15 $36.6 \%)$, enlargement of the subarachnoid spaces $(31-75.6 \%)$, ventricular system (16 $39.0 \%$ ) external hydrocephalus ( $24-58.5 \%)$, internal hydrocephalus $(19-46.3 \%)$, increased or decreased density of cerebral matter of deep and other localization $(25-60.9 \%)$.

One could see the main representative indicators of neuroimaging in the examined contingent of patients.

It is known that epileptiform activitycan be observedimmediately after mild TBI. It is possible to increase the frequency of the $\alpha$-rhythm by several $\mathrm{Hz}$ with subsequent normalization after 3-10 months. In some cases, there may be a general decrease in activity 
and $\alpha$-rhythm disturbances. There may be an increase in beta activity along with the irregular $\alpha$-rhythm, as well as low-amplitude delta activity of a diffuse nature.

The pathological activity of the brain during the first two weeks after trauma increases the risk of PTE. However, there is a discrepancy between the signs of lowering the threshold of convulsive activity and the absence of clinical manifestations of $\mathrm{E}$, which complicates the diagnosis. This means that the diagnosis of PTE is not legitimate when there are electroencephalographic changes in the form of foci of epiactivity and the fact of trauma, and seizures are absent. In such cases, a comprehensive diagnosis using MRI and other modern methods of neuroimaging is required.

In the interictal period in $6(14.6 \%)$ cases on the electroencephalogram of pathological brain activity was not registered.

Half of the observations showed signs of non-specific nature $(21-51.2 \%)$ in the form of disorganization of the main rhythms, frequency, modulation and waveform with a tendency to hypersynchronization.

In $30(73.2 \%)$ observations, the $\alpha$-rhythm index was reduced, low-amplitude polyform activity prevailed, and the high-frequency index increased.

In the structure of bilateral tonic-clonic seizures in $10(66.6 \%)$ patients there were diffuse changes of varying severity. Slow-wave activity - in $6(40.0 \%)$, with sharp waves - 4 (26.7\%). At the same time at additional focal epileptiform activity the index of an $\alpha$-rhythm was low or average.

Focal epiactivity was reported in 15 (57.7\% of all patients with focal seizures). In 4 patients $(15.4 \%)$ this kind of "focus" was determined in the frontal lobes. In $11(42.3 \%)$ - in the temporal. Complexes "sharp-slow wave", "peak-wave", regional sharp waves and their slowing down were revealed. In 6 cases, cerebral changes in bioelectrogenesis with focal activity and low $\alpha$-rhythm index were determined.

The presence of epileptiform activity correlated with a higher frequency of seizures.

It is necessary to take into account the presence of vegetative crises (VC) and comorbid anxiety disorders, which was reflected in a decrease in the activity of $\alpha$-rhythm.

According to neuroimaging data, morphological brain damage and their combination, paroxysmal clinics, as well as the presence and type of short-term focal seizures, the data obtained may indicate the detection of structural-electrofunctional correlates. Such coincidences were characteristic depending on the severity of trauma. Coincidence of clinical manifestations of temporal lobe epilepsy with localization of the focus of neuronal 
hyperactivity in the temporal area was observed in 12 cases $(57.1 \%, \mathrm{p}<0.05)$, the coincidence of clinical manifestations of frontal epilepsy was $37.5 \%$

An important clarifying point in the localization of the focus was the clinical manifestation in the form of short-term focal attacks. In cases of temporal localization, they were necessarily present in the form of vegetative-visceral or, less frequently, cardiovascular manifestations.

Thus, the information obtained takes into account brain damage of varying severity, localization, periods of clinical course of trauma, allows you to diagnose and study its consequences, including PTE.

According to the anamnesis, complaints and observations of patients, the presence of vegetative crisis states was revealed, which complicate the diagnosis, treatment, affect the course of PTE and reduce the quality of life. VC was registered in 24 patients $(58.5 \%$, $\mathrm{p}<0.05$ ). They developed against the background of existing trauma of moderate severity (14 $-58.3 \%, \mathrm{~g}=0.51 ; \mathrm{p}<0.05)$. In cases of mild TBI $-16.7 \%$, with severe CNS injury $-25.0 \%$. Correlations between the type of seizures and the presence of VC: focal (14-58.3\%), focal with subsequent spread to both hemispheres of the brain -7 (29.2\%), bilateral $-3(12.5 \%)$. Incl. focal types prevailed, and taking into account the subsequent bilaterization the expressed correlation of existence of the center of epiactivity and VK was received $(21-78,3 \%, g=0,69$; $\mathrm{p}<0,01)$.

Complaints of cognitive disorders are characteristic of traumatic brain injury, especially in the formation of PTE. Most patients with PTE complained of decreased memory, attention, thinking - $35(85.3 \%)$. These circumstances indicate that decreased motivational-cognitive and other cognitive functions are the leading symptoms of the consequences of TBI and PTE clinics. The state of short-term and long-term memory was studied using a test for memorizing 10 words.

In individuals with mild TBI, the average values of the test at all stages of presentation of words were significantly higher than in groups with more severe trauma, with a violation of selectivity, narrowing the volume of direct and delayed reproduction.

The productivity of random memorization of verbal material was reduced compared to the norm in all groups of patients with final symptoms of trauma of varying severity.

Insufficient intellectual operations were characteristic of severe trauma. The lowest rates were likely compared to normative data and other groups in terms of severity of trauma. Maximum - in the presence of mild TBIin the anamnesis, but they also did not reach the normal distribution of memorization of 10 words according to A. R. Luria's test. 
The volume of maximum reproduction of words in all groups was after the third presentation of verbal material, but it was lower than normal by: $1.2 \pm 0.1$ (mild TBI), $3.7 \pm 0.5$ (moderate, $\mathrm{p}<0,05$ ), $4.8 \pm 0.3$ (severe TBI) words.

Probably the volume of long-term memory decreased, which was confirmed by the violation of long-term word reproduction by: $2.0 \pm 0.2$ (mild TBI); 4.6 \pm 0.4 (moderate, $\mathrm{p}<0.05$ ); $5.8 \pm 0.6$ (severe TBI) words.

Thus, we can assume that in addition to the formed symptomatic epilepsy, the state of memory, attention, thinking is directly affected by the degree of traumatic brain injury in the anamnesis.

It is known that cerebral circulation is a special and independent functional system and is associated with integrative mechanisms controlled by the ANS. Peripheral resistance index - RI and mean linear blood flow rate - LVC of the internal carotid artery (ICA) were registered in all patients with PTE as the most informative department of the carotid system in terms of assessing the state of the ANS and vasomotor reactions. It is known that ICA has no anatomical and age variability, the resistance index determines the neuro-reflex and metabolic processes that are characteristic of traumatic and ischemic brain damage, and also depends little on the location of the sensor angle, researcher skills, age, etc.

RI in the ICA basin was mainly higher than the norm, which indicates the predominance of angiospasm of the vessels of the brain of the studied group of patients. Bilateral changes in mean RI values were insignificant ( $p>0.01)$ and amounted to $0.72 \pm 0.07$ (left); $0.74 \pm 0.06$ (right).

It is known that depressive strata are comorbid in relation to E. In addition, psychoemotional disorders are a leading factor that reduces the quality of life in E. They can be: as a reaction to TBI or PTE on the problem of social adaptation; due to morphological changes in the brain after trauma with the involvement of specific formations that are involved in the formation and maintenance of PTE, as well as contribute to the development of depression (including primary); somatoform disorders, etc.

Depressive symptoms according to HADS were registered in 19 patients (46.3\%). They were more often observed at focal attacks - $12(63,1 \%)$, and taking into account the mixed types of attacks $(6-31,5 \%)$ - focal with the subsequent distribution of epiactivity on a cerebral cortex that in the sum makes $94,7 \%, \mathrm{p}<0.05$.

A larger number of people with pre-existing depression suffered moderate trauma (13 $-68.4 \%, \mathrm{p}<0.05)$, with severe trauma this figure reached $83.3 \%(\mathrm{p}<0.05)$, and with TBI the percentage was significantly less $-20.0 \%$. 
For depression, the temporal localization of the pathological process prevailed $(50.0 \%)$ against the frontal $12.3 \%(\mathrm{p}<0.05)$, while bilateral tonic-clonic seizures were accompanied by depressive symptoms in only one case $(5.5 \%)$.

In the presence of depression, vagotonia prevailed $(9-47.4 \%)$, sympathicotonia and eutonia were evenly distributed $(5-26.3 \%$ each).

Thus, it can be assumed that structural brain damage due to trauma affects the development or maintenance of depressive symptoms.

Concerning alarming symptoms, the prevalence among the examined contingent of persons with PTE was also recorded - 12 (29.3\%), and in some cases this circumstance was interpreted as a normal reaction or as a response to the accompanying PTE symptoms and syndromes.

In contrast to depressive symptoms, the distribution of anxiety strata was relatively uniform and affected all types of seizures.

The ascending tone of the ANS in the presence of anxiety shifted towards sympathicotonia $(10-83.3 \%, \mathrm{p}<0.05)$, which is easier to implement $\mathrm{VC}$, which was observed in $8(66.7 \%)$ cases.

\section{Conclusions}

1. Among the surveyed 41 patients of working agewith PTE, men predominated (75.6\%). There was a reduction in the time of formation of PTE depending on the severity of trauma. The presence of the focal component of seizures reached 90.2\% ( $\mathrm{p}<0.05)$. Inmild TBI bilateral attacks, including with focal onset, and in cases of more severe brain injury, focal, or with subsequent bilateralization.

2. Leading syndromes due to trauma have been identified. In addition to PTE was characterized by autonomic dysfunction syndrome (87.8\%) with paroxysmal course (58.5\%) by type of panic attacks, which developed mainly in people with moderate trauma $(\mathrm{r}=0.51$, $\mathrm{p}<0.05)$.

3. In all examined patients the sympathicotonic orientation of VT prevailed $(56.1 \%, \mathrm{p}$ $<0,05)$. In cases of more severe brain injury, VT shifted toward vagotonia, with a significant increase in the number of generalized seizures and a maximum reduction in the duration of PTE (12.3 \pm 2.1 months), which is 4.2 months less than in the normal distribution of VT.

4. Electroencephalographic parameters did not always show pathological bioelectroactivity $(14.6 \%)$, mostly signs of nonspecific nature were registered, in $36.6 \%$ local focal activity. 
5. Typical comorbid symptoms in people with PTE were cognitive deficits, which correlated with the severity of TBI, as well as depressive and anxiety symptoms. Depressive layers were more often observed in the presence of the focal component of seizures $(94.7 \%$, $\mathrm{p}<0.05$ ), temporal localization of the pathological process and predominant vagotonia. Anxiety manifestations affected all types of attacks on the background of sympathicotonia $(83.3 \%, \mathrm{p}<0.05)$, which in our opinion improved the implementation of crisis situations, which were observed in $66.7 \%$ of cases.

\section{References}

1. Olesen J., Baker M., Freud T., Luca M., Mendlewich J., Ragan I., Westphal M. Consensus document on European brain research. J Neurol Neurosurg Psychiatry. 2006; 77 (Suppl 1):1-49.

2. Akhanov G.Zh., Dyusembekov E.K., Nurbaky`t A.N. Klinikoe’pidemiologicheskie aspekty` cherepno-mozgovoj travmy`. Zhurnal «Nejrokhirurgiya i nevrologiya Kazakhstana». 2017; 47 (2): 65-71 (In Russian).

3. Sabirov D.M., Rosstal naya AL., Makhmudov M.A. E`pidemiologicheskie osobennosti cherepno-mozgovogo travmatizma. Vestnik e`kstrennoj medicziny`. 2019; 12 (2): 61-66 (In Russian).

4. Grimajlo V.N.,LitovchenkoT.A., YakubenkoYu.V., Markova T.V. Osobennosti sindroma vegetativnoj distonii $\mathrm{u}$ paczientov $\mathrm{s}$ posttravmaticheskoj e`pilepsiej. Mezhdunarodny`j mediczinskij zhurnal. 2015; 3: 32-35 (In Russian).

5. Khubieva Z.A., StarodubczevA.A., StarodubczevA.I. Sroki razvitiya posttravmaticheskoj e`pilepsii. Rossijskij nejrokhirurgicheskij zhurnal im. A.L. Polenova. 2013; 5: 307 (In Russian). 